\title{
Evaluation of agropesticides and botanicals for management of yellow vein mosaic virus disease of okra [Abulmoschus esculentus (L.) Moceh.] in Mewar region of Udaipur, Rajasthan
}

\section{B.L. MALI*1 AND DINESH KACHHAWA ${ }^{2}$}

${ }^{1}$ Department of Plant Pathology, Rajasthan College of Agriculture, Maharana Pratap University of Agriculture and Technology, UDAIPUR (RAJASTHAN) INDIA

${ }^{2}$ Department of Entomology, Rajasthan College of Agriculture, Maharana Pratap University of Agriculture and Technology, UDAIPUR (RAJASTHAN) INDIA

\section{ARITCLE INFO}

$\begin{array}{ll}\text { Received } & : 06.06 .2014 \\ \text { Revised } & : 05.08 .2014 \\ \text { Accepted } & : 20.08 .2014\end{array}$

\section{KEY WORDS :}

Yellow vein mosaic virus, Management, Chemicals, Botanicals and Okra

*Corresponding author:

\begin{abstract}
The yellow vein mosaic virus (YVMV) disease of okra [Abulmoschuse sculentus (Linnaeus) Moench.] caused by virus is a common and highly destructive disease in Mewar region of Rajasthan. The experiments were conducted under field condition to develop the effective, safe and economical management strategies through evaluation of agro-insecticides and botanicals. Among insecticides and botanicals evaluated, two foliar sprays of Imidacloprid 17.8 per cent SL and two sprays Azadirachtin were found effective against YVMV disease of okra. Maximum per cent efficacy of disease control (77.6\%) and per cent increase in yield (70.37\%) was recorded when plant were sprayed with Imidacloprid 17.8 per cent SL twice followed by two sprays of Azadirachtin $1500 \mathrm{ppm}$ which was followed by two sprays of Imidacloprid and two sprays of Karanj oil 77.7 per cent and 63.31 per cent increase in fruit yields. All insecticides and botanicals alone or in their combinations increased the fruit yield. However, maximum increase was observed by two sprays of Imidacloprid and two sprays of Azadirachtin, where increase was 79.30 per cent (2011) and 72.60 (2012) as compared to other treatments including untreated control. The minimum white fly population 2.9 plant (2011) and 2.4/plant (2012) was recorded when plant were sprayed with Imidacloprid plus Azadirachtin followed by 2.8/plant (2011) and 3.6/plant (2012) white fly population was recorded when crop was sprayed with Imidacloprid plus Karanj oil.
\end{abstract}

How to view point the article : Mali, B.L. and Kachhawa, Dinesh (2014). Evaluation of agropesticides and botanicals for management of yellow vein mosaic virus disease of okra [Abulmoschus esculentus (L.) Moceh.] in Mewar region of Udaipur, Rajasthan. Internat. J. Plant Protec., 7(2) : 364-368. 